\title{
An Inverse Correlation between Corn Temperature and Nitrogen Stress: A Field Case Study
}

\author{
Heba Alzaben,* Roydon Fraser, and Clarence Swanton
}

\begin{abstract}
Nitrogen is one of the most important yield-limiting nutrients for corn (Zea mays). The ability of thermal remote sensing to detect nitrogen deficiency in corn may enable precision agriculture to modify nitrogen rates according to field conditions. This study applies the exergy destruction principle as a theory to explain the inverse relationship between surface temperature and nitrogen rate. Two hypotheses were developed. First, it was hypothesized that agricultural crops experiencing greater growth and providing greater yield will have lower surface temperature. The second hypothesis was that corn grown under optimum levels of nitrogen will have lower surface temperatures compared to corn grown under nitrogen stressed conditions. Field studies were conducted during two summer seasons (2016 and 2017) on an established long-term field trial of corn yield response to varying rates of nitrogen. It was found that corn surface temperature decreased as the rate of nitrogen increased. A shallow but statistically significant $(P<0.05)$ negative slope was observed consistently with increasing rates of nitrogen. Surface temperature measurements, however, were variable. This variability was the result of external and weather dependent variables that influenced leaf surface temperature. Despite this variability, the exergy destruction principle provides a theory from which thermal remote sensing can be applied through the use of surface temperature measurements to detect physiological stress in crop plants.
\end{abstract}

\section{Core Ideas}

- Thermal remote sensing was proposed to detect nitrogen stress in corn plants.

- Nitrogen stressed plants had higher surface temperatures than less stressed plants.

- Temperature trends were consistent with the exergy destruction principle.

- Nitrogen-temperature correlations were statistically significant at the 0.05 significance level.

- Corn yield increases with nitrogen rate increase and surface temperature decrease.
$\mathrm{N}$

ITROGEN IS one of the most important yield-limiting nutrients for corn (Zea mays) production worldwide (Subedi and Ma, 2009). Different methods have been used to detect nitrogen stress in corn, such as tissue analysis, transmittance, reflectance, and florescence methods (Chlingaryan et al., 2018; Corti et al., 2018; Muñoz-Huerta et al., 2013). All of these methods, however, have limitations. Tissue analysis was found to be time consuming and damaging to plant tissues (Goffart et al., 2008). Alternatively, nondestructive methods were used, such as leaf transmittance, through a hand-held soil plant analyses development (SPAD) chlorophyll meter, canopy reflectance, and chlorophyll fluorescence methods (Muñoz-Huerta et al., 2013; Xie et al., 2018). The SPAD meter was found to be highly variable (Martínez and Guiamet, 2004; Xiong et al., 2015) and affected by leaf location, solar irradiance, and leaf water status (Martínez and Guiamet, 2004; Vigneau et al., 2011; Zhang et al., 2009). Limitations of reflectance-based methods include lack of sensitivity for stress detection at early growth stages and high sensitivity to variation in sunlight and soil conditions (Apostol et al., 2007; Muñoz-Huerta et al., 2013; Padilla et al., 2018, 2019). Chlorophyll fluorescence measurements were reported to more accurately sense nitrogen independently from soil background noise, leaf area, and biomass status (Heege et al., 2008; Tremblay et al., 2012). However, hand-held devices, such as Multiplex (FORCE-A, Orsay, France), require a distance of approximately $10 \mathrm{~cm}$ between the sensor and the plant, therefore limiting its usefulness on large field scales (Muñoz-Huerta et al., 2013; Yao et al., 2012).

Thermal remote sensing is proposed as a means of stress detection in crops as it is nondestructive, noncontact, rapid assessment capability, easy use, and more accurate than previously mentioned methods (Ahmed et al., 2018; Das et al., 2018; Khanal et al., 2017). Thermal remote sensing has been used to detect differences in canopy temperatures between water stressed and nonstressed plants (Idso et al., 1981; Jackson et al., 1981, 1982) and nitrogen stressed plants (Blad et al., 1988; Carroll, 2015; Ward, 2015). Blad et al. (1988) found a nonconsistent relationship between nitrogen stress and canopy temperature in different locations and years across Canada. Carroll (2015) investigated the effect of varying nitrogen rates

H. Alzaben, R. Fraser, Dep. of Mechanical and Mechatronics Engineering, Univ. of Waterloo; C. Swanton, Plant Agricultural Dep., Univ. of Guelph, Guelph, ON, N1G 2W1, Canada. Received 23 Apr. 2019. Accepted 26 July 2019. *Corresponding author (halzaben@uwaterloo.ca).

Abbreviations: FTIR, Fourier transform infrared; NUC, nonuniformity correction; ROI, region of interest; SPAD, soil plant analyses development. publisher. 
on leaf surface temperature for corn grown under full and limited irrigation conditions. They found a nonsignificant relationship between nitrogen rate and leaf surface temperature under two water stress levels in both greenhouse and field conditions. In contrast, Lu and Zhang (2000) observed a significant effect, with an inverse relationship, between nitrogen rate and surface temperature associated with heat stress detection. Ward (2015) investigated the effect of varying nitrogen and water stress levels on canopy temperature, and found that both canopy temperature and canopy-air temperature difference provided an equally significant sensitivity to plant stress. Akbari (1996) measured the temperature difference between leaf surface and air temperature in corn to distinguish between different nitrogen-stress levels using a hand-held point measurement infrared gun. In this experiment, it was observed that leaf surface temperature differences decreased with increasing nitrogen rate. These observations supported the idea that leaf surface temperature can be used as an indicator of complexity and development, which enabled the plant to degrade energy.

Energy has both magnitude and quality. The quality of energy is defined as exergy; it measures the ability of the system to do useful work (Bonati et al., 2019; Cengel and Boles, 2002; Fraser and Kay, 2004). Energy degradation occurs when the quality of energy decreases. It is not referred to the reduction in quality as energy dissipation, because the concept of energy quality involves not only entropy, where entropy production is often referred to as dissipation (Glansdorff and Prigogine, 1971; Prigogine, 1991), but also environment consideration.

Exergy has three main properties. First, it is context sensitive because it is formulated with respect to a reference environment; that is, if the environment temperature and pressure changes then the exergy changes even if there was no change to the corn plant or ecosystem (Cengel and Boles, 2002; Valero, 2008; Wall, 1977). Second, exergy is universal because it can be used as a common decision making tool; that is, it enables all systems to be compared with the common basis of energy quality, in other words, their ability to do useful work (Fraser and Kay, 2004; Gaudreau, 2009). Third, exergy is not conserved because, unlike energy, it can only be destroyed but not created (Knudsen, 2016; Valero, 2008; Wall 1977). Furthermore, it has been found that more developed ecosystems tend to utilize more exergy from the incoming solar radiation, and these are more efficient in exergy destruction compared to less developed ecosystems (Akbari, 1996; Jørgensen, 2000; Kay, 2000; Lawrence, 2016).

The exergy destruction principle states that an ecosystem will develop in a way to maximize the amount of work available for the purpose of structural organization, function, and survival (Kay, 2000; Schneider and Kay, 1994a, 1994b). Ecosystems are examples of nonequilibrium, complex, nonlinear, and discontinuous thermodynamic systems. Ecosystems exist in high ordered state and their complexity increases over time (Schrödinger, 1944). Schneider and Kay (1994a, 1994b) suggest that more developed ecosystems are more efficient at energy dissipation than less developed ecosystems, thus their surface temperature is lower compared to less developed ecosystems. Luvall and Holbo (1989) used a thermal infrared multispectral scanner over a 400-m transact with different land covers; a significant difference of $10^{\circ} \mathrm{C}$ was observed in surface temperature among varying land covers. The more developed the land cover, the cooler the surface temperature. More developed ecosystems have larger biomass to accommodate the increase in complexity, which is correlated with development (Schneider and Kay, 1994a, 1994b). Lin et al. (2018) showed a theoretical relationship between entropy production, exergy destruction, and forest canopy temperature. According to the Gouy-Stodola theorem, the exergy destruction is directly proportional to entropy production through the environment reference temperature (Cengel and Boles, 2002). The relationship between entropy production and surface temperature was based on the similarity between the ecosystem and the Bénard cell (Lin et al., 2018). It was found that exergy destruction decreases with increasing canopy temperature, which supports the findings in the literature (Kay, 2000; Luvall and Holbo, 1989; Schneider and Kay, 1994a, 1994b).

Maximizing development corresponds to maximizing organization (Finn, 1988; Kay, 2000). To the best of our knowledge, this concept has never been applied to a plant system. Plant systems are characterized as complex, nonlinear, open thermodynamic systems, capable of exchanging matter and energy with their surrounding (Prigogine, 1991). From an engineering-thermodynamic perspective, a plant system can be modeled as a thermodynamic black box with input and output energy and mass flows (Lawrence, 2016). Therefore, all the physiological processes and mechanisms used to raise or lower surface temperature, such as transpiration, respiration, photosynthesis, and reflectance, are implicitly taken into account and not directly considered in this work.

From an exergy balance perspective, the maximum work available to a plant system exists at the lowest surface temperature (Lawrence, 2016). Based on the exergy destruction principle that ecosystem organization can be measured using surface temperature, and that more developed ecosystems have larger biomass, it is hypothesized that agricultural crops experiencing greater growth and providing greater yield will have lower surface temperatures. Plant stress will affect plant growth and development (Cools and De Veylder, 2009; Duncan et al., 1965; Lee et al., 2008). When a plant is stressed with an external stress factor (e.g., excess heat, insects, or lack of nutrients), its functions (e.g., transpiration, respiration, and photosynthesis) will also be affected. Highly stressed plants experience less growth and development. Therefore, given that a crop experiencing greater growth and development will have a lower surface temperature, and that crop stress reduces growth and development, it is also hypothesized that corn grown under optimum levels of nitrogen will have lower surface temperatures than corn grown under nitrogen stressed conditions. The main objective is to determine if surface temperature can be used to predict nitrogen stress in corn plants at early growth stages. More specifically, our objective is to determine if there is an inverse correlation between surface temperature and nitrogen stress, yield reduction as predicted by the exergy destruction principle.

\section{MATERIALS AND METHODS}

In 2008, a long-term field trial was established at the Elora Research Station, Elora Ontario, to determine the response of corn yield to varying rates of nitrogen. This experimental study was conducted on a silt clay loam soil $\mathrm{pH} 7.7$, organic matter of $3.5 \%$. The total test area was $1.72 \mathrm{ha}$. Individual plots consisted of six rows of corn, $76 \mathrm{~cm}$ between rows and approximately $15 \mathrm{~m}$ in length by $4.5 \mathrm{~m}$ wide. Nitrogen rates of $0,28,57,115,188$, and 
$230 \mathrm{~kg} \mathrm{~N} \mathrm{ha}^{-1}$ were applied at planting. The nitrogen formulation used was Urea Ammonium Nitrate (UAN, 28v/v). The UAN was injected between rows every year. A starter nitrogen fertilizer of $30 \mathrm{~kg} \mathrm{ha}^{-1}$ was applied at the time of planting. In addition, weeds were controlled prior to corn planting using the herbicide Callisto (Mesotrione, Syngenta) at $0.3 \mathrm{~L} \mathrm{ha}^{-1}$ along with Primextra II Magnum ( $S$-metolachlor and atrazine, Syngenta) at $3.5 \mathrm{~L} \mathrm{ha}^{-1}$.

A soil nitrate sampling to a depth of 0 to $30 \mathrm{~cm}$ was conducted prior to corn planting in May each year, where five cores per plot were taken and mixed. A nonsignificant difference among all nitrogen treatment plots was found in soil nitrate levels prior to the addition of fertilizer each year. This implies that the amount of nitrogen added in the previous year does not affect the following year. The volumetric water content of the soil was measured over different plots within the field using an EC5 soil moisture sensor (Decagon Devices Inc., Pullman, WA, US) inserted into 10-cm depth below ground.

Corn hybrid 'DeKalb DKC 3987' (DEKALB Canada, Chatham, ON, Canada) was planted on 17 May 2016 and 11 May 2017 at a seeding rate of 79,000 seeds per hectare. The corn hybrid required 2700 heat units with 2000 growing degree days to mature. The starter fertilizer (i.e., 15-15-15-2 Zn) was applied in a band at a distance of $5 \mathrm{~cm}$ from the row at a depth of $5 \mathrm{~cm}$. Standard agronomic practices were applied to optimize corn growth and development. Conventional fall tillage with a plow was used. In addition, the average rainfall was approximately $75 \mathrm{~mm}$ per month.

Each individual plot was machine harvested on 1 November 2016 and 7 November 2017. Yield was reported at 15\% moisture level.

\section{Thermal Image Acquisition}

Temperature measurements were initiated on 5 June 2016 and 1 June 2017 at the three-leaf tip stage (i.e., V2 stage) of the corn seedling growth using a high-resolution research thermal camera (T620 series, FLIR Systems, Canada). Leaf surface temperatures were collected from the middle two rows to avoid any border effects from the neighboring plots. The thermal camera specifications included a 640 by 480 resolution thermal detector, field of view 25 by $19^{\circ}$, a standard temperature range of -40 to $650^{\circ} \mathrm{C}$, spectral range of 7.5 to $14 \mu \mathrm{m}$, thermal sensitivity less than $0.04^{\circ} \mathrm{C}$ at $30^{\circ} \mathrm{C}$ temperature, accuracy of $\pm 2^{\circ} \mathrm{C}$, and precision of $0.1^{\circ} \mathrm{C}$. FLIR T620 camera has an uncooled microbolometer that is very sensitive to temperature drift of the camera housing (Gong and Wasserman, 2019). The thermal camera powered on for at least $10 \mathrm{~min}$ prior to thermal image acquisition to minimize the effect of vignetting (Israel, 2016). In addition, a manual nonuniformity correction (NUC) was performed before taking every image to reduce the fixed pattern noise (Niklaus et al., 2008; Sui et al., 2013) and maintain good image quality. The manual NUC involves the selection of a calibration function to force the thermal detector to recalibrate the location of every pixel in the image (i.e., minimize the drift).

The thermal camera and a hand-held point measurements infrared gun were used to measure surface temperatures. Each plot consisted of approximately 200 corn plants distributed in six rows. Three plants per plot from the middle two rows were selected for leaf temperature measurements. The top side of a youngest fully expanded sunlight leaf was consistently selected for leaf temperature measurements. The hand-held infrared gun, which was used to measure the on-site leaf surface temperature, was consistently held $50 \mathrm{~cm}$ away and perpendicular to the top side of the leaf surface. Canopy temperatures were measured using the thermal camera mounted on a 5-m aboveground tripod with a setup distance in the camera of $5 \mathrm{~m}$ from the plot. Previous studies identified the canopy thermal radiation variances with sensor view angle (Kimes et al., 1980; Kirkham, 2005; Krayenhoff and Voogt, 2016; Nanda et al., 2018). Consequently, the thermal camera images of the canopy were consistently taken perpendicular to the plant surface, that is, in the nadir direction.

The thermal camera calculated surface temperature from the incident thermal radiation on the thermal detector. Different parameters were required for the user to input to the camera, prior to thermal image acquisition, in order to obtain an accurate estimate of object temperature. Such parameters include: surface emissivity, distance from the camera lens to the object, reflected apparent temperature, atmospheric temperature, and relative humidity. The thermal camera corrected the object temperature for atmospheric and sky background variation.

Prior to field temperature measurements, an average emissivity of 0.96 was determined under controlled laboratory conditions, based on the 7.5 tol $4 \mu \mathrm{m}$ band as determined from corn leaf emissivity measurements using a Fourier transform infrared (FTIR) reflectometer (Surface Optics corporation SOC400T, San Diego, $\mathrm{CA}$ ). The reflected apparent temperature was measured each time prior to surface temperature measurements using the procedures described in the thermal camera's user manual and the guidance of ISO18434-1. In addition, the thermal camera was calibrated using a blackbody source (463 Cavity black-body, Infrared Industries, Hayward, CA). The difference between the thermal camera measurement and the standard reference temperature was no more than the accuracy of the thermal camera $\left( \pm 2^{\circ} \mathrm{C}\right)$. In the field, the thermal camera was calibrated before every measurement using the Programmable NUC set in the camera. Surface temperature measurements in 2016 and 2017 were recorded twice a week around noon time over approximately 2 -h period under clear sky or uniform overcast conditions for a uniform sky background radiation assumption. Surface temperature measurements continued on a weekly basis until the corn silking stage.

The reflected apparent temperature was estimated using a crumbled aluminum foil (i.e., to reduce the specular reflection) placed in front of a leaf surface (Jones et al., 2002; Maes and Steppe, 2012). Surface temperatures were corrected for meteorological conditions on different days due to temperature measurement sensitivity to solar irradiance, air temperature, relative humidity, and wind speed (Fuchs, 1990; Maes and Steppe, 2012; Maes et al., 2017; Yazici and Kaynak, 2006). Leaf and canopy temperatures were corrected for the variation in air and soil temperatures. In addition, plant geometry, emissivity, inclination, and orientation of corn leaves within corn canopy can also generate leaf temperature variation, therefore, an average surface temperature was calculated to reduce the geometryrelated effects (Chauhan and Opeña, 2013).

\section{Processing of Thermal Images}

Surface temperatures were extracted from the collected thermal images using FLIR ResearchIR (FLIR Systems Inc., Boston, MA, version 3.5) and Matlab R2017B (Mathworks Inc., Natick, 


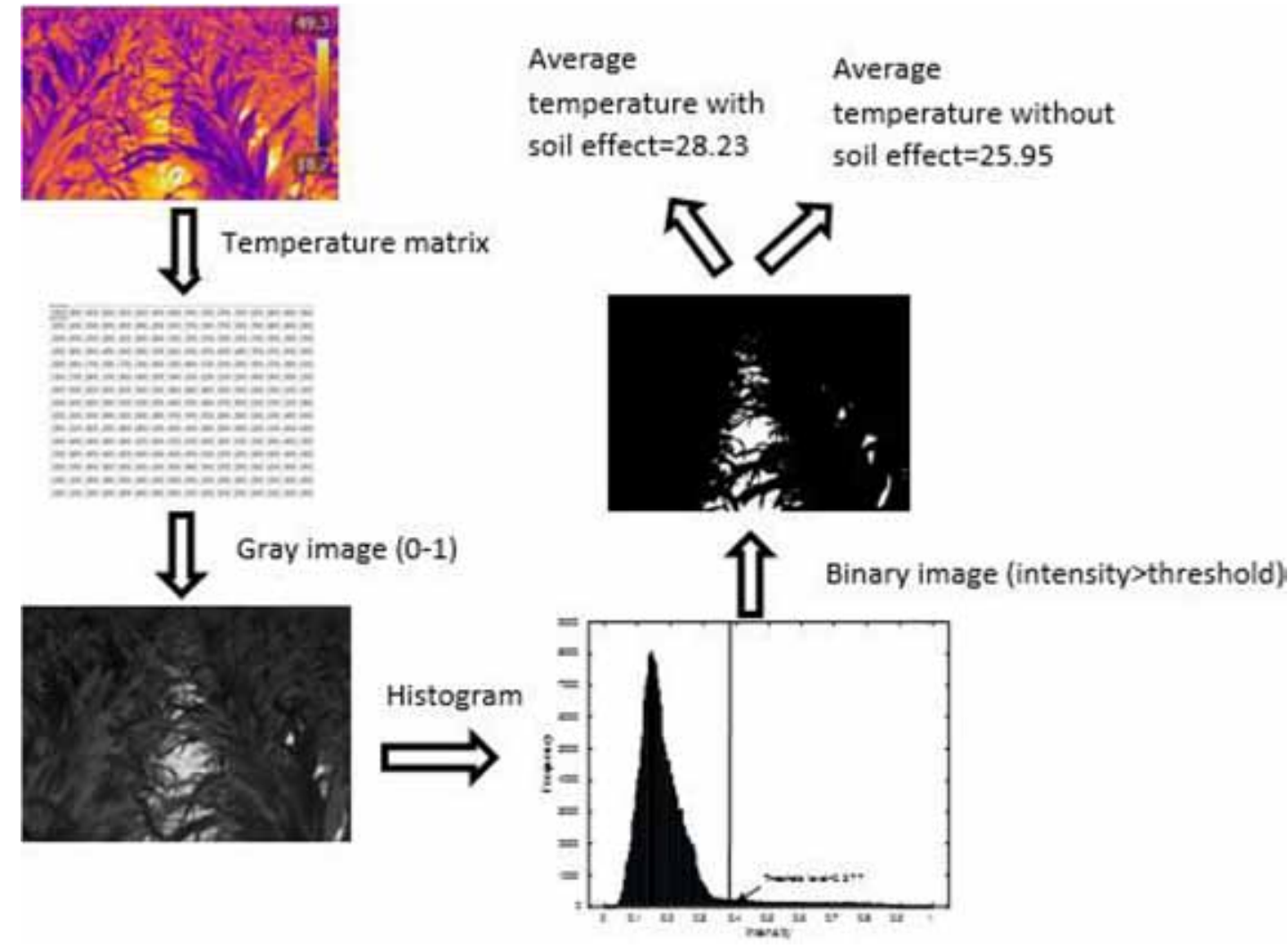

Fig. I. Thermal image segmentation using thresholding algorithm.

MA) software. Multiple thermal images were collected for the same plot to calculate the variance in temperature measurements. The pixel value in each thermal image represents the temperature of that pixel because a radiometric thermal camera was used (FLIR T620). Thermal images were converted to 'csv' file using ResearchIR, then imported into Matlab and analyzed using image processing toolbox. The average and maximum temperatures were extracted from each region of interest (ROI). The ROI over a leaf surface was defined as a rectangular box of approximately 2000 pixels, approximately $0.03 \mathrm{~m}^{2}$, when calculating leaf surface temperature. In addition, the ROI was defined over multiple plants as a rectangular box with 100,000 pixels, approximately $1.5 \mathrm{~m}^{2}$, for canopy temperature measurements. The raw 14-bit data, Metadata of thermal images, and calibration constants were extracted using Exiftool (Harvey, 2016), and the raw images were processed in Matlab and converted to temperature using equations described in detail in Di Felice et al. (2018).

Thermal images were subjected to a segmentation thresholding algorithm. Specifically, the Otsu method (Otsu, 1979; Shrestha et al., 2004) using Matlab's graythresh function, which was applied to determine the optimal threshold level, creating a binary image identifying areas of soil and corn plants. Figure 1 provides a summary of the method for creating a binary image. The binary image is multiplied by the original image to isolate the plants by $1^{s}$ and $0^{s}$ corresponding to plants and soil, respectively. To isolate the soil, the $1^{s}$ and $0^{s}$ in the binary image were reversed. Finally, an average canopy temperature for the plants was calculated. As an example (Fig. 1), the difference in average canopy temperature, between averaging the temperature of the plants only versus averaging the temperature of the entire image, was approximately $3^{\circ} \mathrm{C}$.
The measured leaf and canopy temperatures are affected by the variations in soil and air temperatures. Air temperature was measured using a type $T$ thermocouple attached to a corn plant at 2-m height, where the tip of the thermocouple was exposed and measured the surrounding air canopy temperature. Soil temperatures were extracted from thermal images. The following two equations represent the corrections that were applied to leaf and canopy temperatures:

$$
\begin{aligned}
& T_{\mathrm{cc}}=T_{\mathrm{c}}-T_{\mathrm{a}}+T_{\mathrm{a} \text { mean }} \\
& T_{\mathrm{cc}}=T_{\mathrm{c}}-T_{\text {soil }}+T_{\text {soil mean }}
\end{aligned}
$$

where $T_{\mathrm{cc}}$ is corrected canopy temperature, $T_{\mathrm{c}}$ is canopy temperature $\left({ }^{\circ} \mathrm{C}\right), T_{\mathrm{a}}$ is air temperature $\left({ }^{\circ} \mathrm{C}\right), T_{\mathrm{a} \text { mean }}$ is mean air temperature $\left({ }^{\circ} \mathrm{C}\right), T_{\text {soil }}$ is soil temperature $\left({ }^{\circ} \mathrm{C}\right)$, and $T_{\text {soil_mean }}$ is soil mean temperature $\left({ }^{\circ} \mathrm{C}\right)$.

Atmospheric correction is an important step in extracting accurate temperature data. Atmospheric transmission $(\tau)$, which is a function of relative humidity, atmospheric temperature, and distance between the object and the camera sensor, was calculated using equations described in details in Di Felice et al. (2018) and Minkina and Dudzik (2009). For the canopy temperature measurements, the maximum distance between the crop surface and the thermal camera sensor was $5 \mathrm{~m}$. At this distance, atmospheric transmittance was estimated as 0.986 and the relative temperature error was $0.1 \%$, which can be assumed to be negligible. 
(a)

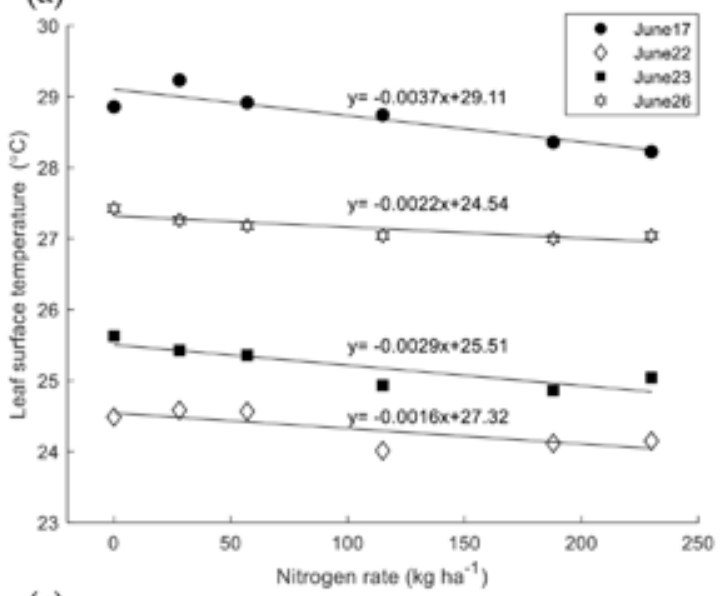

(c)

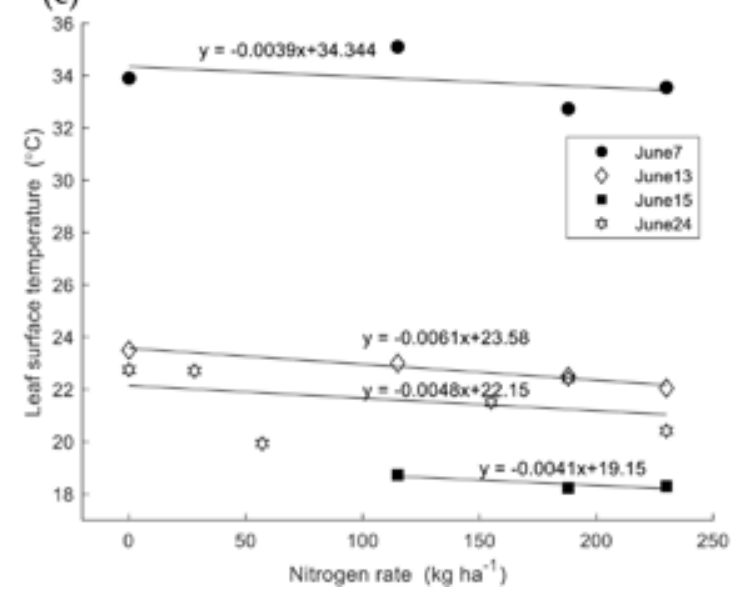

(b)

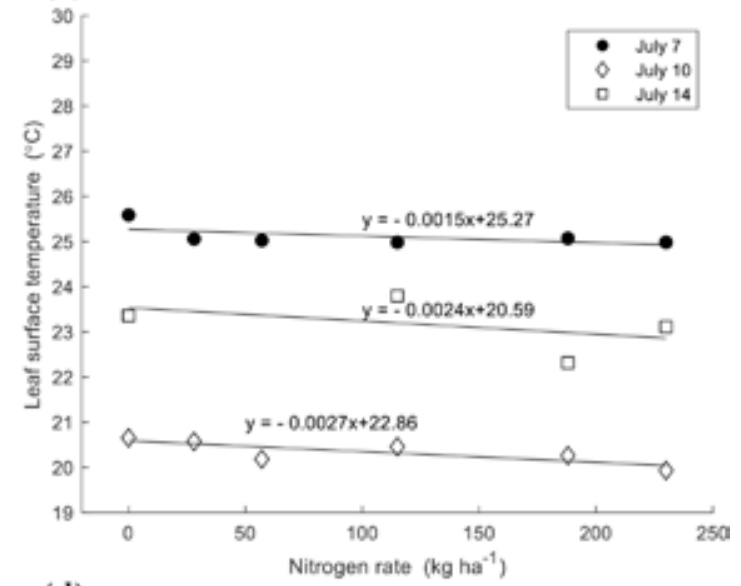

(d)

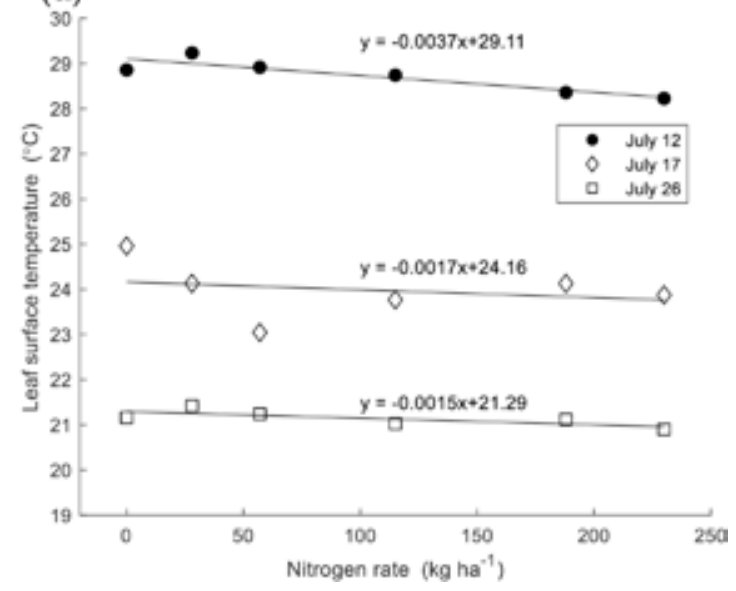

Fig. 2. The mean leaf surface temperature as influenced by nitrogen rate (a) June 2016, (b) July 2016, (c) June 2017, (d) July 2017. Each temperature data point represents an average of 12 temperature measurements per day ( 3 measurements times 4 replications for each nitrogen rate per day).

\section{Whorl Temperature Measurement Using Thermocouples}

Whorl temperatures for selected nitrogen treatments were measured using a type $\mathrm{T}$ thermocouples with FEP-Insulated Probe (Digi-Sense, Cole-Parmer, Montreal, Quebec) for continuous temperature measurements. Thermocouples were inserted into the whorl of corn plants to reduce the error associated with different radiation levels. Each thermocouple wire was attached to a mini-connecter. Thermocouples were connected to a 12-channel datalogging thermometer with an SD card (Extech DT4208SD, Cole-Parmer). Whorl temperature data were collected at the same time with thermal images over short period of time (approx. 1 min between the measurements).

\section{Meteorological Conditions}

Leaf and canopy temperature measurements were affected by many weather related variables such as: solar irradiance, air temperature, wind speed, and relative humidity (Knížková et al., 2002). Wind speed, air temperature, and relative humidity were measured $2 \mathrm{~m}$ above the ground using a mobile Vantage Vue weather station (Davis Instrument, Hayward, CA). The sampling rate was set to $1 \mathrm{~Hz}$, and 15 -min averages of data were recorded. In addition, more metrological data including rainfall precipitation rate, solar radiation, and longwave radiation were provided from a nearby weather station, which was approximately $1.5 \mathrm{~km}$ from the study site. Wind speed, relative humidity, and solar radiation were compensated through conditional sampling, and days with low wind speed in the range of 0.3 to $1.3 \mathrm{~m} \mathrm{~s}^{-1}$ were selected for temperature data acquisition.

\section{Data Analysis}

Statistical data analysis was conducted on the collected leaf and canopy temperature measurements using Matlab software. Analysis of variance (ANOVA) using an F-test was applied to investigate the effect of different nitrogen treatments on surface temperature. Leaf surface temperatures were collected on different days in 2016 and 2017 as an average of three measurements per plot for four replications within the field. A significant difference in leaf surface temperature between each of nitrogen treatments was confirmed after conducting a linear regression based ANOVA at a 0.05 significance level. In addition, Pearson correlation analysis was used to investigate the relationship between yield and leaf temperature.

Regression analysis was also applied individually to each of the four replications on all days for which temperature measurements were presented. In these 16 datasets (i.e., $4 \mathrm{~d}$ times four replications), three nonsignificant positive slopes, five nonsignificant negative slope, and eight significant negative slopes were observed. This variability in temperature data is not unexpected, given the slopes are shallow, the large data variability, 


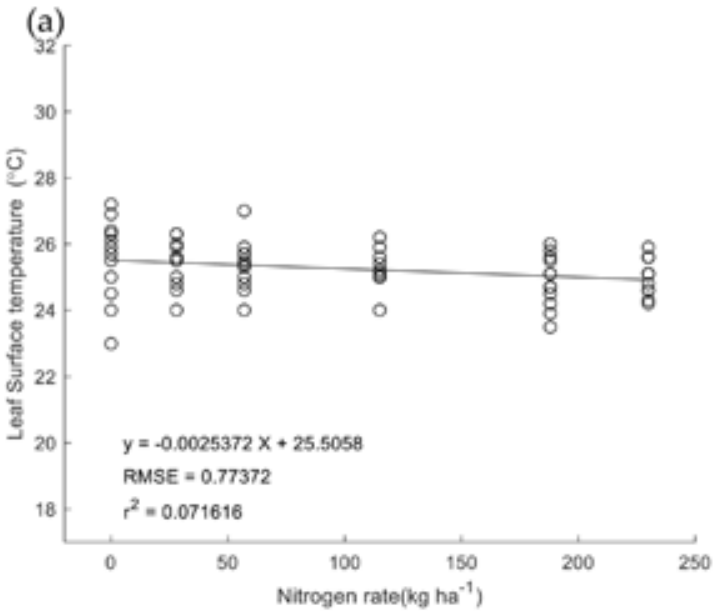

(c)

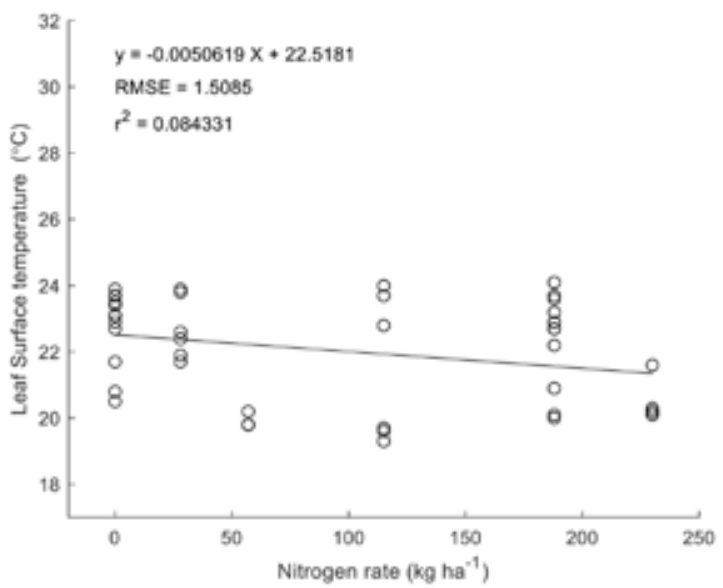

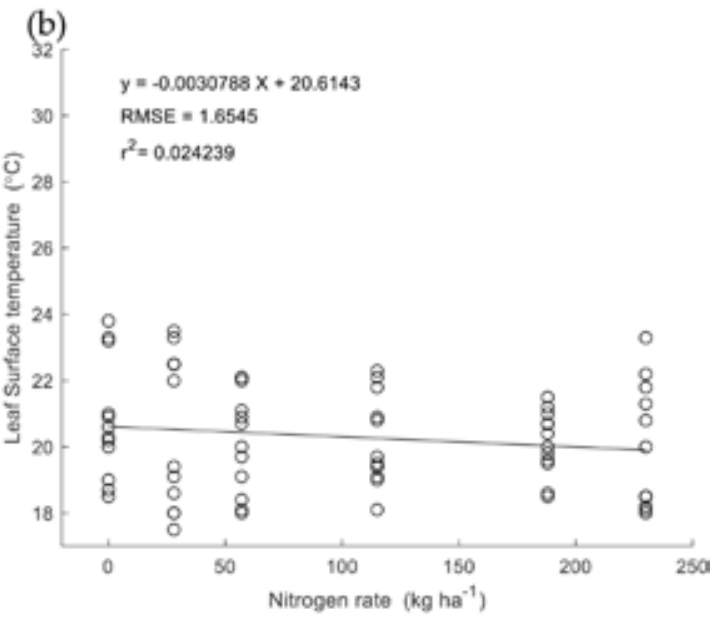

(d)

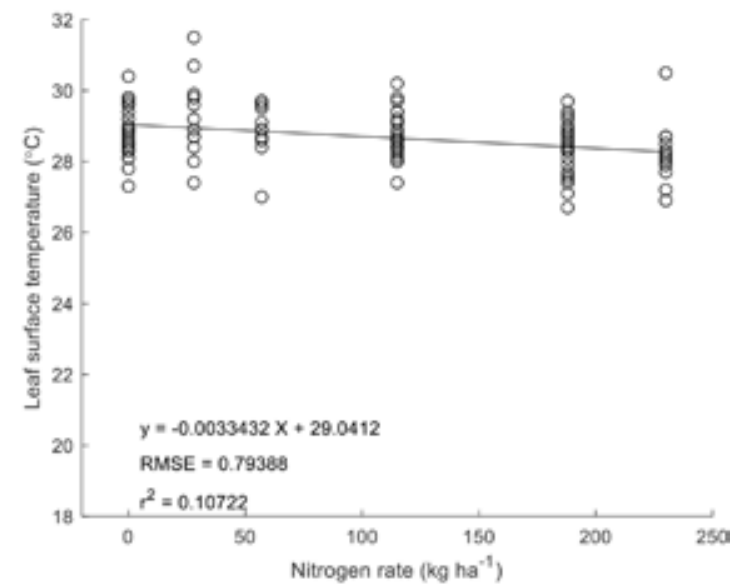

Fig. 3. The effect of increasing nitrogen rate on leaf surface temperature on different days over 2 -yr period (a) June 232016 , (b) July 10 2016, (c) June 242017 , (d) July 122017.

the three data points per nitrogen treatment in each dataset per replication, and the assumed $95 \%$ significance level, therefore, the general observation of a consistent negative slope remains unchanged.

A paired $t$-test with an equal variance assumption was used to compare the nitrogen treatments. A linear regression analysis was conducted to investigate the relationship between increasing nitrogen rate and decreasing surface temperature. Corn yield data were analyzed using ANOVA analysis to determine the significant increase in yield with increasing nitrogen rate. A quadratic regression model was chosen as the best fit to nitrogen rate versus grain yield data (Sui et al., 2017). Unless otherwise stated, the significance level was chosen as $P \leq 0.05$.

\section{RESULTS AND DISSCUSSION}

\section{Leaf Surface Temperature Decreased with Increasing Rates of Nitrogen}

Corn leaf surface temperature decreased as the rate of nitrogen increased. A shallow but statistically significant negative slope was observed consistently with increasing rates of nitrogen on a daily basis throughout the months of June and July for both 2016 and 2017 (Fig. 2). For example, on June 26 and July 10 2016 , the 0 nitrogen rate had a mean leaf surface temperature of $27.5^{\circ} \mathrm{C}$ and $20.8^{\circ} \mathrm{C}$, compared to $27^{\circ} \mathrm{C}$ and $19.9^{\circ} \mathrm{C}$, respectively, for corn that received $230 \mathrm{~kg} \mathrm{ha}^{-1}$ of nitrogen. The average air temperatures on these two days were $27.9^{\circ} \mathrm{C}$ and $23.4^{\circ} \mathrm{C}$ during the time of temperature data collection, and the leaves supplied with $0 \mathrm{~kg} \mathrm{ha}^{-1}$ and $230 \mathrm{~kg} \mathrm{ha}^{-1}$ of nitrogen were at 12 to 13 and 14 to 15 leaf stage, respectively. On 24 June and 12 July 2017, the 0 nitrogen rate had a mean leaf surface temperature of $22.8^{\circ} \mathrm{C}$ and $28.9^{\circ} \mathrm{C}$, compared to $20.4^{\circ} \mathrm{C}$ and $28.2^{\circ} \mathrm{C}$, respectively, for corn that received $230 \mathrm{~kg} \mathrm{ha}^{-1}$ of nitrogen. The average air temperatures on these two days were $22.9^{\circ} \mathrm{C}$ and $25.8^{\circ} \mathrm{C}$, and the leaves supplied with $0 \mathrm{~kg} \mathrm{ha}^{-1}$ and $230 \mathrm{~kg} \mathrm{ha}^{-1}$ of nitrogen were at 10 to 11 and 14 to 15 leaf stage, respectively. Figure 3 shows the temperature data for the four replications per nitrogen treatment on a single graph for a given day. For example, on June 23 2016, for the 0 nitrogen rate, leaf surface temperature ranged from 23.0 to $27.2^{\circ} \mathrm{C}$ and for the $230 \mathrm{~kg} \mathrm{ha}^{-1}$ rate of nitrogen, the leaf temperature ranged from 24.2 to $25.9^{\circ} \mathrm{C}$ (Fig. 3). A similar response was observed in 2017. Despite the large temperature variability between corn plants within and between the four replications, the regression analysis consistently identified a negative slope, as presented in Fig. 3, where the RMSE is the calculated root mean squared error, supportive of the hypothesis that nitrogen stress affects surface temperature.

Despite this small difference in leaf surface temperature between the low and high nitrogen rates, a significant difference was also observed among nitrogen treatments when analyzed through ANOVA (Table 1). A $P$-value of $0.00012(<<0.05)$ 
(a)
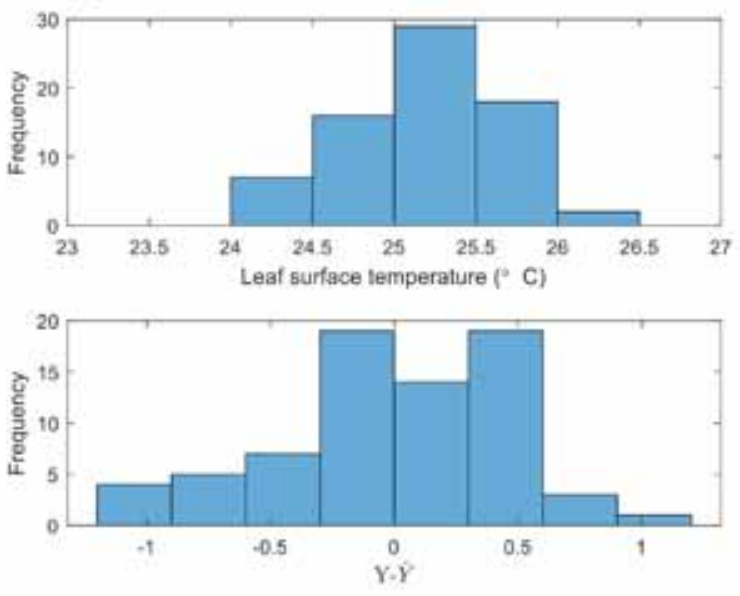

(b)
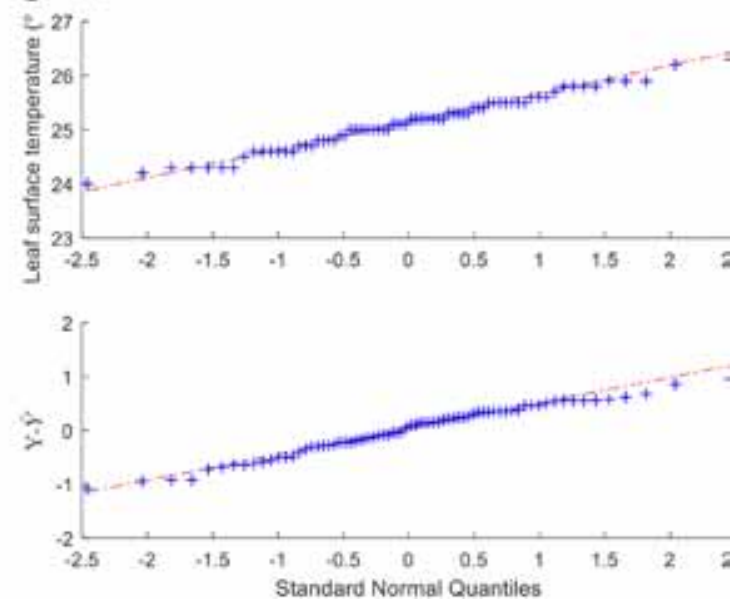

Fig. 4. An example of approximately normal distribution and random error assumptions from July sixth 2016 data (a) leaf surface temperature and temperature residual $(Y-\hat{Y}$, where $Y$ is leaf temperature, and $\hat{Y}$ is predicted leaf temperature) distribution (b) $Q-Q$ plot for leaf surface temperature and temperature residual.

confirmed the significant difference among the six nitrogen treatments regrading leaf surface temperature on July 62016. As an example to validate the assumptions of ANOVA and linear regression for random error and normal data distribution, Q-Q and frequency distribution plots were investigated for temperature data and residuals (Fig. 4) for July 62016 . The residual $(Y-\hat{Y})$ was calculated by subtracting leaf temperature $(Y)$ from the predicted leaf temperature $(\hat{Y})$ obtained by least square linear fit model. Finally, a consistent difference in leaf surface temperature between stressed and non-stressed corn plants with nitrogen rate started to appear when the plants were at 4 to 5 leaf tip stage (i.e., V3 stage), at which stage the plants were no longer provided with nutrients from the seed (Dovrat et al., 2018; Neild and Newman, 1990).

Table I. An example of significant difference across the six nitrogen treatments on 6 July 2016.

\begin{tabular}{|c|c|c|c|}
\hline $\mathrm{N}$ rate & $\begin{array}{l}\text { Measurement } \\
\text { points }\end{array}$ & $\begin{array}{c}\text { Avg } \\
\text { temperature }\end{array}$ & Variance \\
\hline \multicolumn{4}{|c|}{$\longrightarrow{ }^{\circ} \mathrm{C}$} \\
\hline 0 & 12 & 25.7 & 0.09 \\
\hline 28 & 12 & 25.1 & 0.21 \\
\hline 57 & 12 & 25.0 & 0.29 \\
\hline 115 & 12 & 25.0 & 0.11 \\
\hline 188 & 12 & 24.9 & 0.29 \\
\hline 230 & 12 & 24.9 & 0.09 \\
\hline \multicolumn{4}{|c|}{ ANOVA analysis results } \\
\hline Source of variation & SSt $\quad d f \neq$ & MS§ F_calcI & $P$-value $F$ _crit\# \\
\hline Between $\mathrm{N}$ rates & 5.425 & $1.08 \quad 5.99$ & $0.00012 \quad 2.35$ \\
\hline Within $\mathrm{N}$ rate & 11.966 & 0.18 & \\
\hline Total & $17.4 \quad 7 \mid$ & & \\
\hline
\end{tabular}

$\uparrow$ Total sum of the squares which is related to the total variance in the data. $\ddagger$ Degree of freedom.

§ Mean squared error which is generated by dividing SS over $\mathrm{df}$.

If Calculated $\mathrm{F}$ value through dividing mean square of regression (MSR) for $\mathrm{N}$ amount and days over the mean square of error (MSE).

\# Critical $\mathrm{F}$ value that is determined using $\mathrm{F}$-tables with corresponding degrees of freedom for numerator (mean square of regression, MSR) and denominator (mean square of error, MSE).

\section{Canopy Temperature Decreased with Increasing Rates of Nitrogen}

Canopy temperatures decreased as the rate of nitrogen increased. A shallow but consistent negative slope was observed with increasing rates of nitrogen (Fig. 5, 6). As an example, on June 72017 , the mean canopy temperature for plants that received 0 nitrogen was $33^{\circ} \mathrm{C}$ compared to $31^{\circ} \mathrm{C}$ for corn that received $230 \mathrm{~kg} \mathrm{ha}^{-1}$ of nitrogen (Fig. 5). In addition, canopy temperature difference was calculated between the average zero applied nitrogen plots and the five nitrogen treatments (i.e., 28, $\left.57,115,188,230 \mathrm{~kg} \mathrm{ha}^{-1}\right)$ on different days in June and July 2016 and 2017 (Fig. 7). The increasing relationship between canopy temperature difference and nitrogen rate was significant, which supports the hypothesis that with increasing nitrogen rate, surface temperature decreases.

\section{Whorl Temperatures Decreased with Increasing Rates of Nitrogen}

Whorl temperatures decreased as the rate of nitrogen increased. Less variability in temperature measurements was

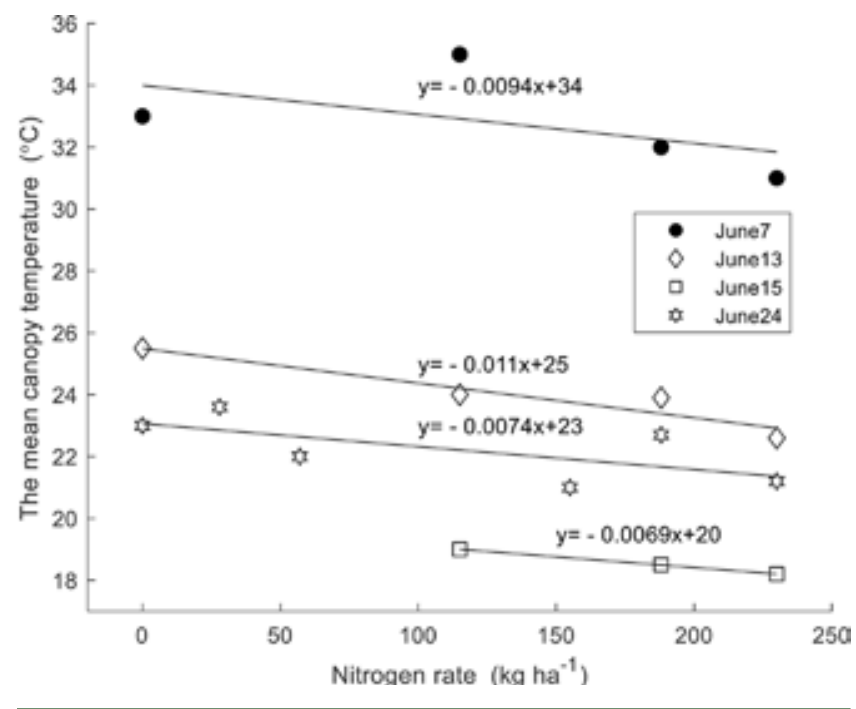

Fig. 5. The mean canopy temperature and nitrogen rate on different days in June 2017 
(a)

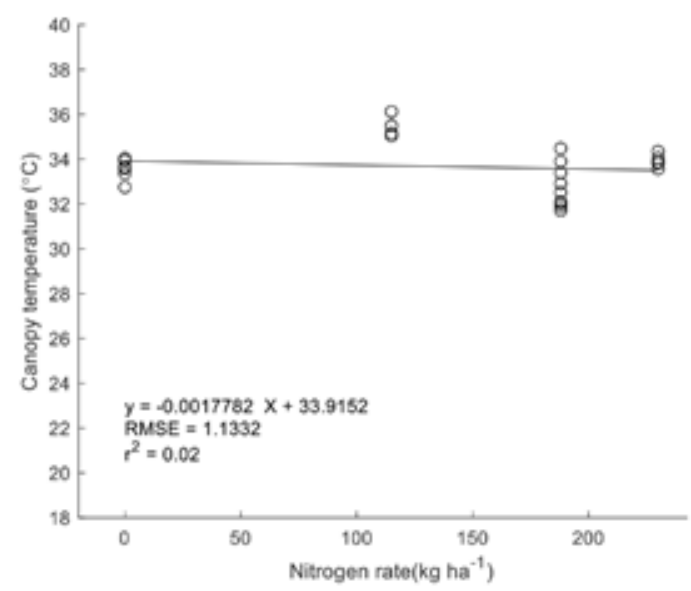

(c)

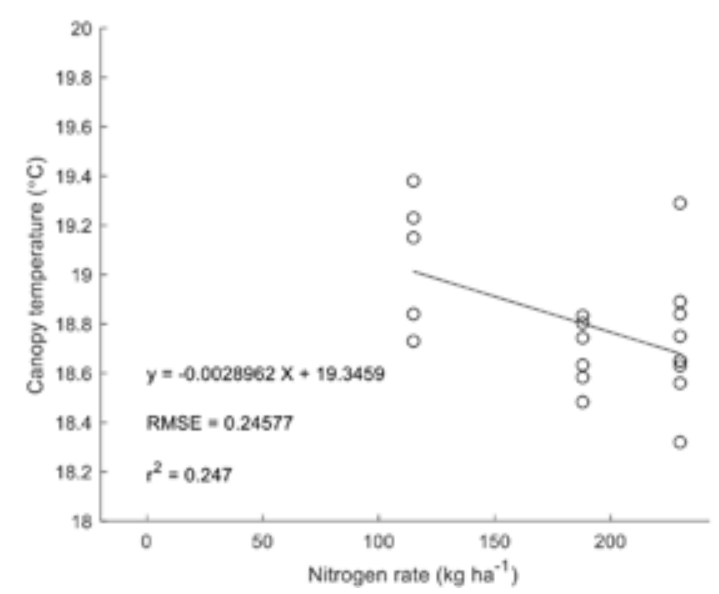

(b)

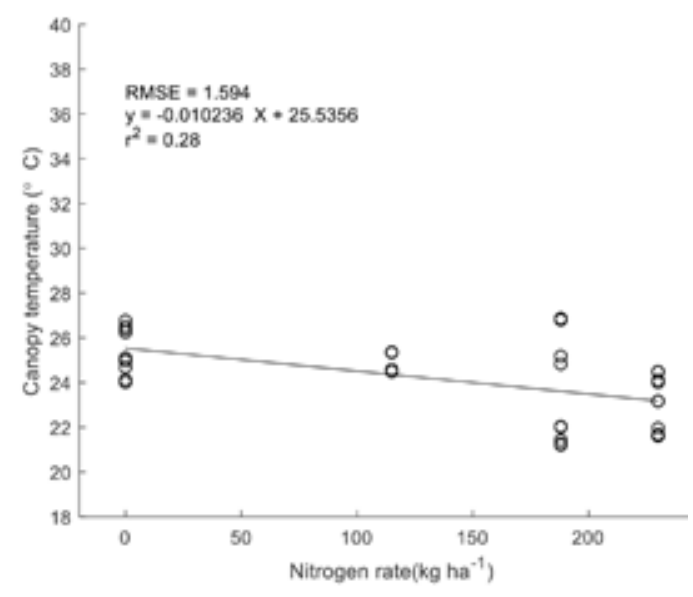

(d)

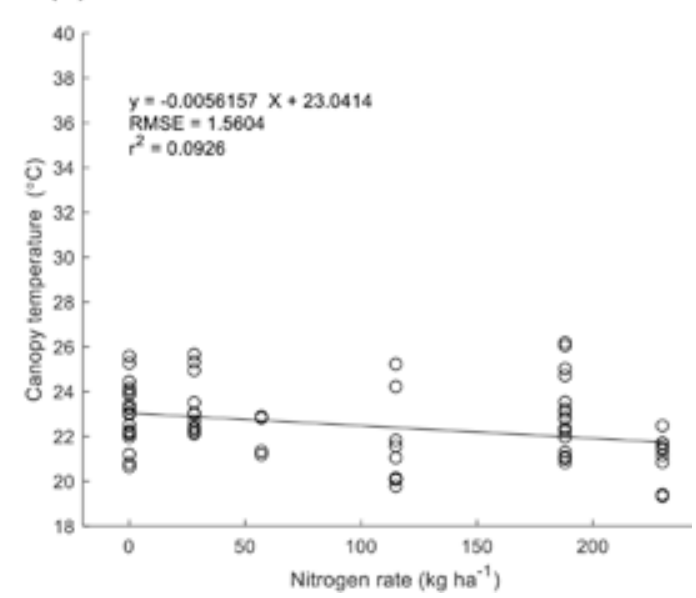

Fig. 6. An inverse correlation between canopy temperature and nitrogen rate presented on different days in June 2017 (a) June 7, (b) June 13, (c) June 15, (d) June 24.

observed when thermocouples were inserted into the whorl of corn plants and measured on a smaller time scale (i.e., minutes and seconds). It was observed that whorl temperatures decreased with increasing rates of nitrogen (Fig. 8). As an example, two nitrogen rates were investigated (i.e., 0 and $188 \mathrm{~kg} \mathrm{ha}^{-1}$ ) to study the relationship between whorl temperature and nitrogen rate. On July 142016, whorl temperatures were measured consistently in the evening and were higher for 0 nitrogen rate compared to $188 \mathrm{~kg} \mathrm{ha}^{-1}$ rate of nitrogen. The trend in Fig. 8 is explained by different weather-dependent variables that affect whorl temperature, such as air temperature, wind speed, and variation in solar radiation. An average air temperature obtained from a nearby weather station is included in the caption for each day of temperature measurements (i.e., air temperature ${ }^{\circ} \mathrm{C}$ ) with an average difference in air temperature of $1^{\circ} \mathrm{C}$ was found during whorl temperature measurements.

\section{Yield Increased with Increasing Rates of Nitrogen and Surface Temperature Decreased}

Yield increased with increasing rates of nitrogen, and surface temperature decreased. A plateau relationship was expected between increasing nitrogen rate and yield, however, for the range of nitrogen rates investigated (i.e., 0 to $230 \mathrm{~kg} \mathrm{ha}^{-1}$ ) a quadratic function was found to fit the nitrogen rate versus grain yield data as presented in Fig. 9. In Ontario, Canada, the optimum nitrogen rate is variable and considered to be in the range of 150 to $170 \mathrm{~kg}$ $\mathrm{ha}^{-1}$ (personal communication, C. Swanton) which is a balance between increasing yield and nitrogen fertilizer. Within each nitrogen rate there was a considerable variability in grain yield. For example, in 2016 at $188 \mathrm{~kg} \mathrm{ha}^{-1}$ nitrogen the yield response ranged from 10100 to $12500 \mathrm{~kg} \mathrm{ha}^{-1}$ with a $2400 \mathrm{~kg} \mathrm{ha}^{-1}$ difference across the four replications within the field. A similar response was observed in 2017. This range in yield variability was similar to the variability found in surface temperatures. Corn yield was negatively correlated with leaf surface temperature prior to harvest, as yield increased leaf surface temperature decreased (Fig. 10). A significant negative correlation between surface temperature and yield was observed, indicating that yields tend to increase as surface temperature decreases (Bai and Purcell, 2018). As a conclusion, it was observed that surface temperatures collected mid-season (i.e., June and July) were negatively correlated with end of season yield (i.e., Oct. and Nov.), indicating that surface temperatures collected in June and July have predictive relative yield potential.

\section{DISCUSSION}

It was required to check if corn plants were under water stress conditions during the growing season in 2016 and 2017, therefore, the soil volumetric water content and precipitation 
(a)

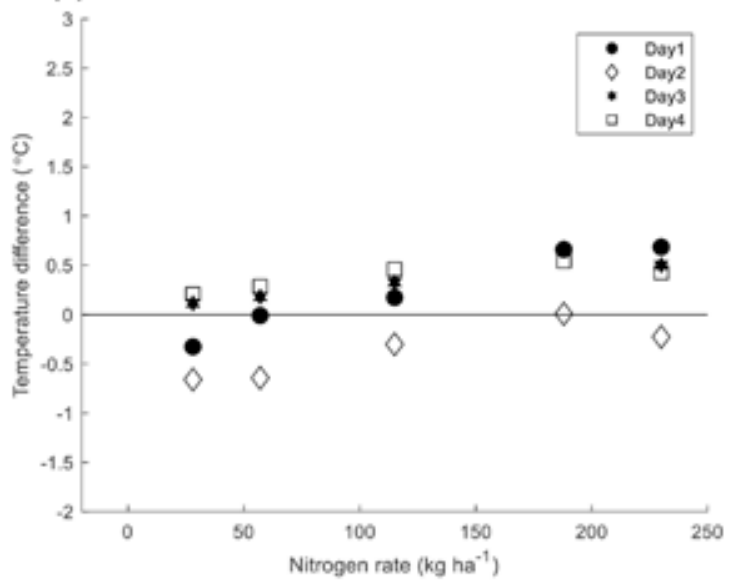

(c)

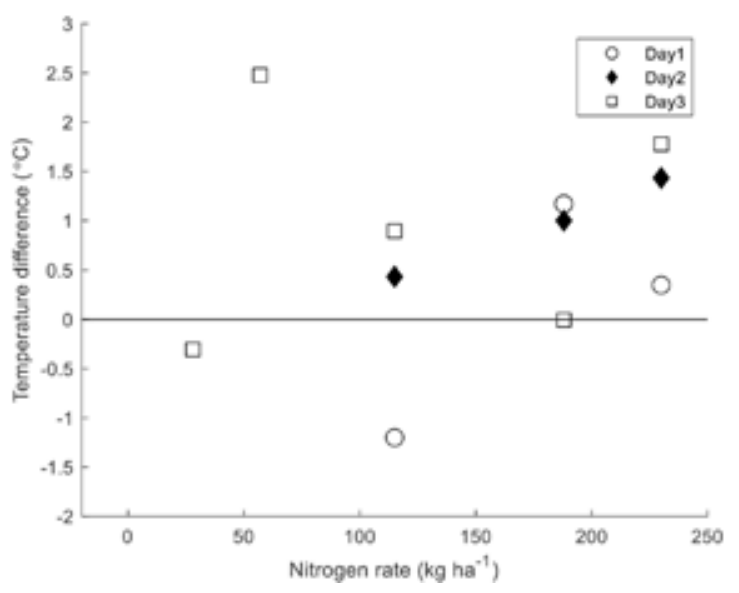

(b)

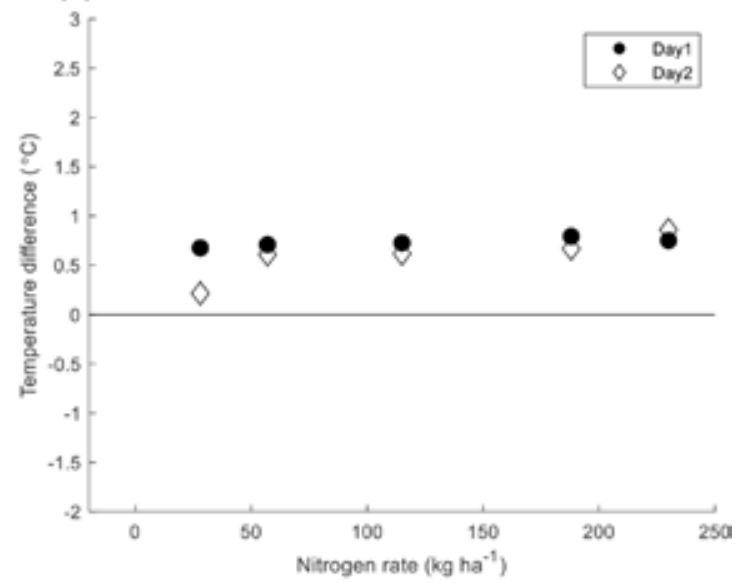

(d)

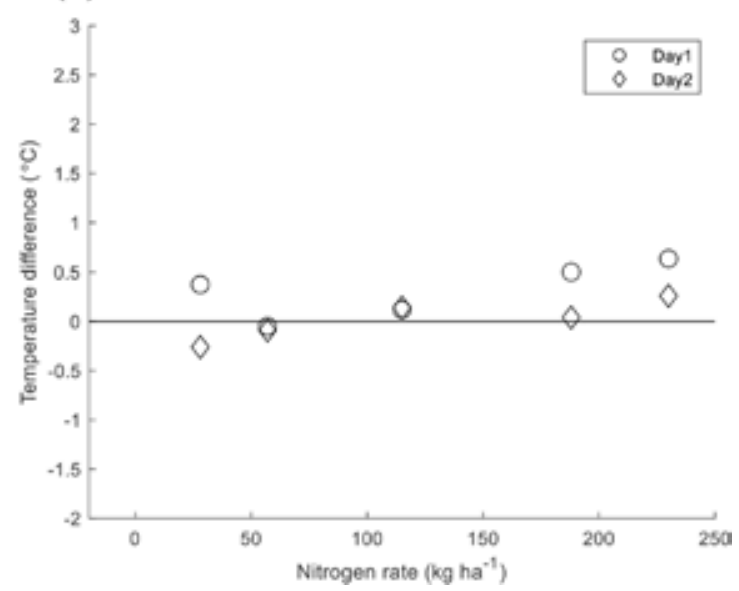

Fig. 7. The relationship between temperature difference $\left(T_{\text {Low }} \mathrm{N}^{-} T_{\text {High } N}\right)$ and nitrogen rate, where $T_{\text {Low }} \mathrm{N}$ represents the temperature collected at low nitrogen rate and $T_{\text {High } \mathrm{N}}$ represents the temperature collected at high nitrogen rate, and the numbers in brackets are the maximum, minimum, and average error [max, min, avg ${ }^{\circ} \mathrm{C}$ ], (a) June 2016 [I.14, $0.193,0.66^{\circ} \mathrm{C}$ ], (b) July $2016\left[0.967,0.307,0.62^{\circ} \mathrm{C}\right.$ ], (c) June 2017 [1.84, $\left.0.26,1.03^{\circ} \mathrm{C}\right]$, (d) July $2017\left[2.45,0.27,1.28^{\circ} \mathrm{C}\right]$.

rate were monitored over the 2 -yr period. In 2016, the average soil volumetric water content during the growing season (i.e., June-August) for plots supplied with $0 \mathrm{~kg} \mathrm{ha}^{-1}$ and $188 \mathrm{~kg} \mathrm{ha}^{-1}$ of nitrogen were $26.07 \% \pm 0.062$ and $24.06 \% \pm 0.056\left(\mathrm{~m}^{3}\right.$ $\mathrm{m}^{-3}$ ), respectively. In 2017 , the volumetric water contents were $25.07 \% \pm 0.074$ and $22.0 \% \pm 0.048\left(\mathrm{~m}^{3} \mathrm{~m}^{-3}\right)$, respectively. For the precipitation rates in 2016 , the average rate per day during the growing season was $5.76 \pm 8.59 \mathrm{~mm}$ and in 2017 was 4.19 $\pm 6.17 \mathrm{~mm}$. These results are within the field capacity range of $22 \%$ to $28 \%$ for silt clay loam soil (Ratliff et al., 1983), and, when coupled with observations of no wilting, they indicate that the corn plants did not experience significant water stress. Even if there were brief periods of water stress, it was effectively uniform across plots, as ensured by the randomized block design of the plots. Therefore, even if water stress did affect the corn surface temperature, it would only shift the temperature and not affect the temperature difference trends induced by the nitrogen differential stressor.

The results obtained from this work suggest that leaf, canopy, and whorl temperatures are inversely correlated with increasing nitrogen rates and increasing yield. This relationship is in support of the two proposed hypotheses. Decreasing leaf and canopy temperatures with increasing yield (Fig. 10) supports the first hypothesis that corn experiencing greater yield will correspond to lower surface temperatures. In addition, decreasing leaf and canopy temperatures with increasing nitrogen rate (i.e., decreasing stress) as presented in Figs. 2, 3, 5, and 6, support the second hypothesis that corn grown under optimum levels of nitrogen will have lower temperatures compared to corn grown under nitrogen stressed conditions.

Temperature measurements were highly variable. This variability was explained by many external and weather dependent variables that interact with leaf, canopy and whorl temperatures. Such variables include the variation in solar irradiance, air temperature, soil temperature, soil moisture, relative humidity, wind speed, cloud cover, leaf angle, leaf emissivity, sensor view angle, and many other factors. Therefore, if the non-nitrogen related variables can be controlled, or compensated through conditional sampling, a comparison of relative temperatures between plants would meet the basic needs for an experimental design to support or reject the proposed two hypotheses. The extent of this variability was found to change day to day, further suggesting the influence of these variables on changing plant temperature.

The error in temperature difference between stressed and less stressed plants was related to the camera precision error, not the camera accuracy. The error in the mean temperature difference can be statistically reduced as the number of temperature measurements increases (i.e., $\sigma_{\text {mean }}=\sigma \mathrm{n}^{-1 / 2}$ ). As an example, for 
(a)

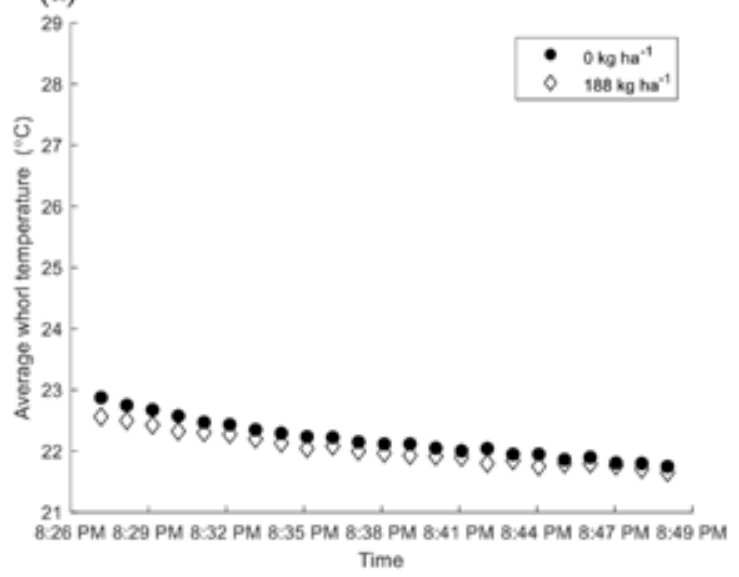

(c)

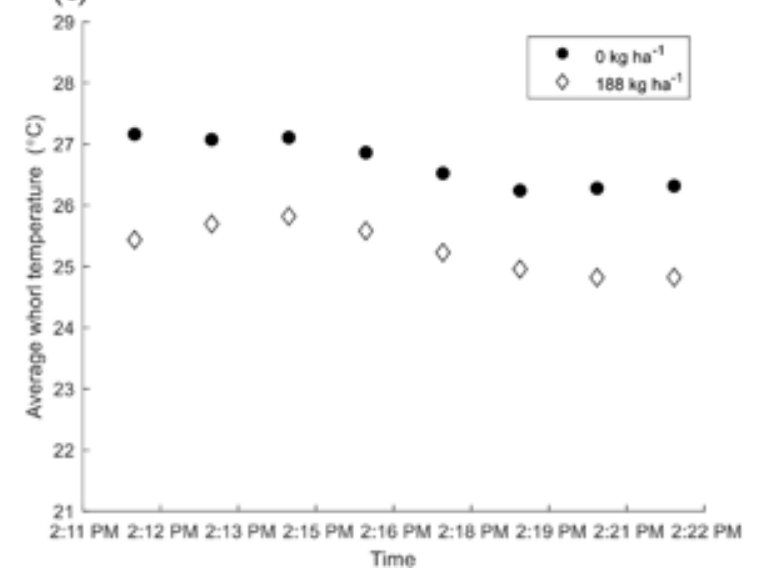

(b)

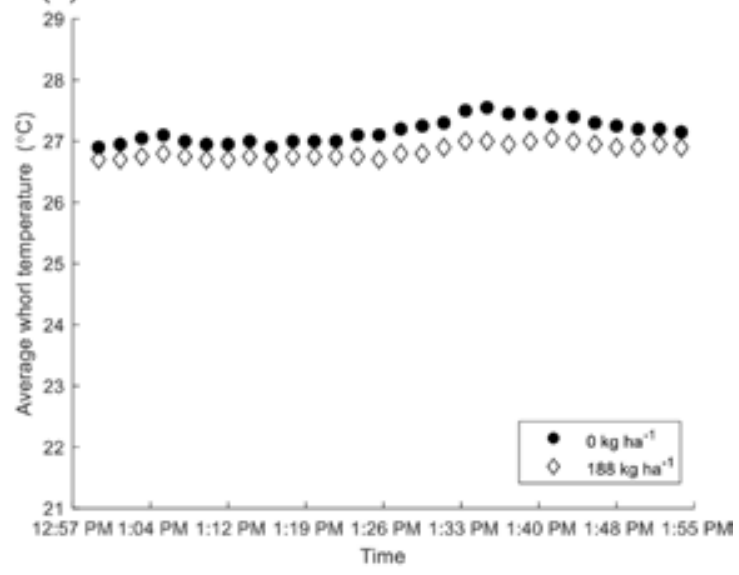

(d)

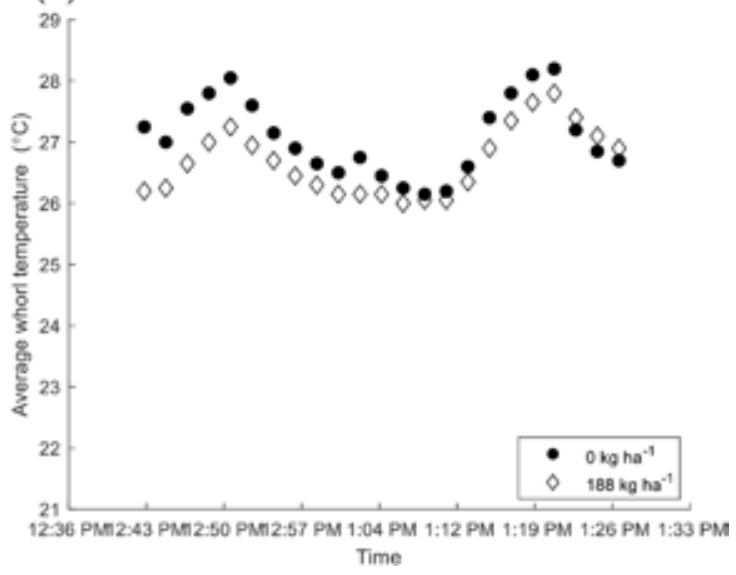

Fig. 8. Average whorl temperatures and nitrogen rate as presented on different days over 2 -yr period (a) July $142016, T_{\text {mean }}$ air $=21^{\circ} \mathrm{C}$; (b) July $162016, T_{\text {mean air }}=19.9^{\circ} \mathrm{C}$; (c) July $122017, T_{\text {mean air }}=23.16^{\circ} \mathrm{C}$; (d) July $172017, T_{\text {mean air }}=22.4^{\circ} \mathrm{C}$. In (a), measurements were recorded in the evening on a 5 -s interval. In (b), (c), and (d), temperature measurements were recorded around solar noon on a 2-min interval.

the temperature measurements collected on June 242016 , the average statistical error in the mean temperature was $0.49^{\circ} \mathrm{C}$, so when coupled with the precision error using Gaussian error propagation, the net error on the mean difference was $0.53^{\circ} \mathrm{C}$.

In this work, the ecosystem is the corn plant system, which clearly demonstrated an increase in development, growth, complexity, and yield with increasing rates of nitrogen. When a corn

(a)

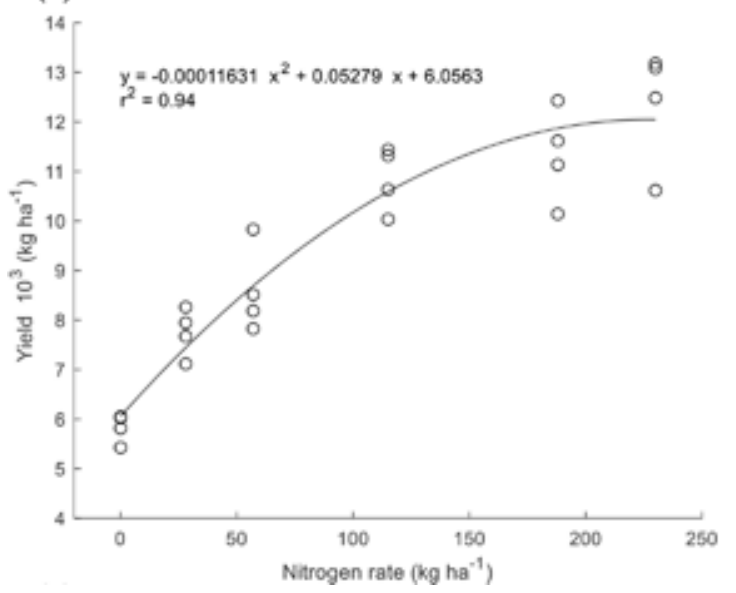

plant is stressed by the lack of nitrogen, all the functions including transpiration, respiration, and photosynthesis are affected, resulting in less growth and development (Lambers et al., 2008; Lee et al., 2008) compared to less stressed plants. Therefore, less stressed plants were more developed and complex, thereby enabling more efficient energy degradation and utilization of solar exergy compared to highly stressed plants. Stress affects

\section{(b)}

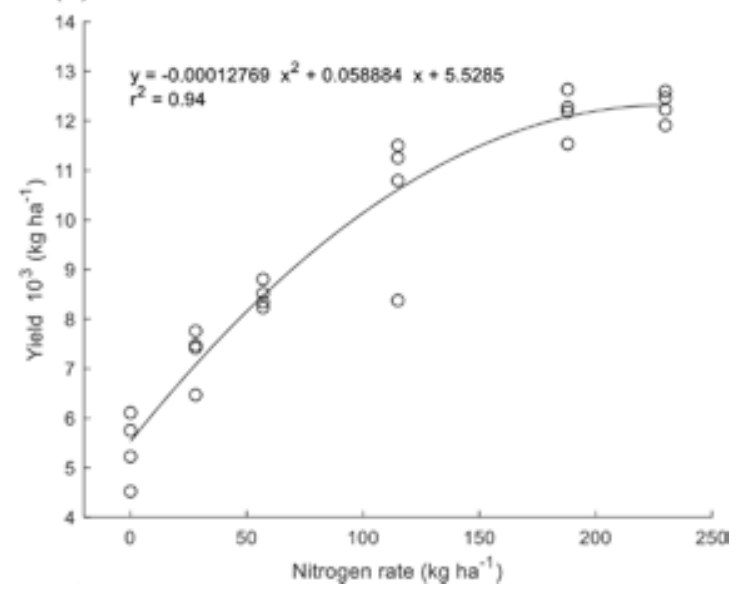

Fig. 9. The effect of increasing nitrogen rate on corn yield in (a) 2016, (b) 2017. 
(a)

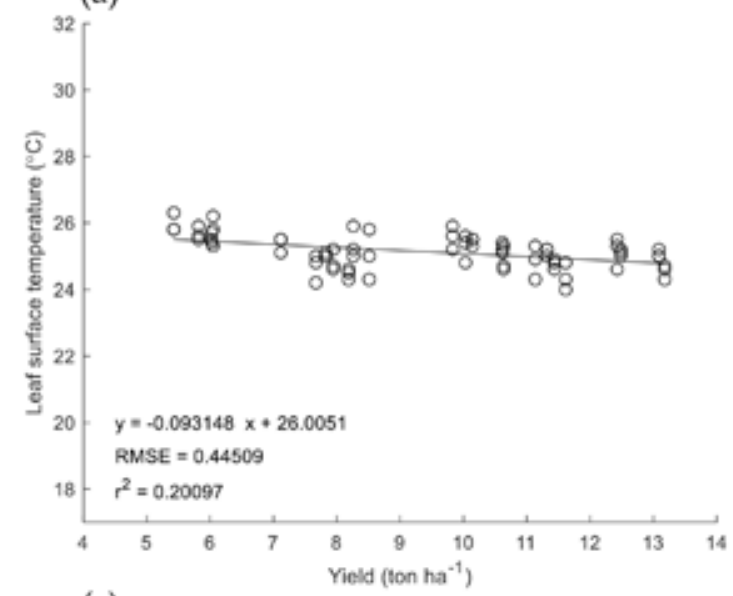

(c)

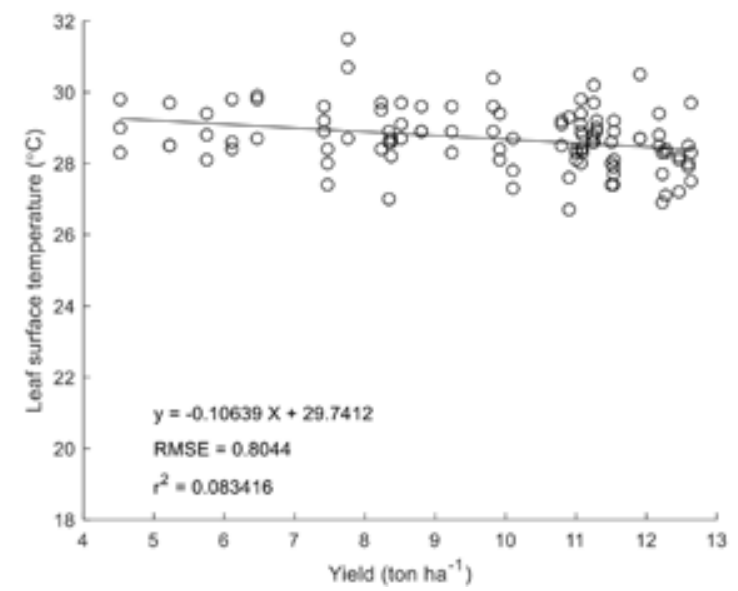

(b)

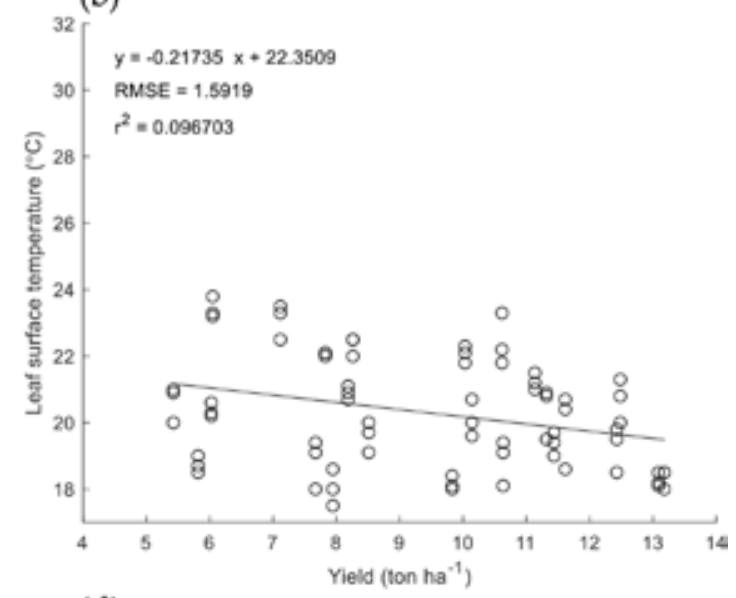

(d)

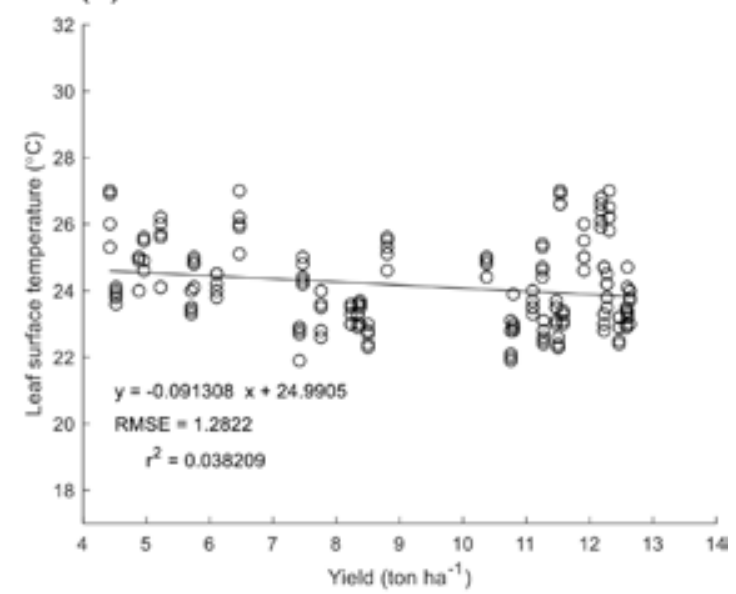

Fig. I0. Inverse correlation between leaf surface temperature and total yield on different days over 2-yr period (a) July 62016 , (b) July I0 2016, (c) July 12 2017, (d) July 172017.

the plants ability to utilize the solar exergy and degrade it (Lawrence, 2016). This efficient degradation of energy results in lower surface temperatures, as suggested by the exergy destruction principle (Kay, 2000).

In conclusion, the inverse relationship between decreasing temperature and increasing yield and increasing nitrogen rate held true despite the large variability associated with each temperature measurement. A statistically significant difference, at 0.05 significance level, was observed in temperatures between stressed and less stressed corn plants. An approximate $1^{\circ} \mathrm{C}$ variation between corn plants that experienced different levels of development (i.e., yield and leaf stage) due to nitrogen stress was a reasonable magnitude, given that ecosystems with a wider variation in development observed approximately $5^{\circ} \mathrm{C}$ average variation (Luvall and Holbo, 1989; Quattrochi and Luvall, 2004). The exergy destruction principle provides a theory from which thermal remote sensing can be applied, through the use of surface temperature measurements, to detect physiological stress in crop plants.

\section{ACKNOWLEDGMENTS}

This research was undertaken in part thanks to funding from the Growing Forward 2 (GF2), a federal-provincial-territorial initiative. The Agricultural Adaptation Council assisted in the delivery of GF2 in Ontario, Canada. The authors would also like to acknowledge the support of the Natural Sciences and Engineering Research Council of
Canada (NSERC). Furthermore, the authors would like to thank the staff from University of Guelph, ON, Canada for providing the required facilities and equipment for conducting field trials for this study.

\section{REFERENCES}

Ahmed, A., A. Ibrahim, and S. Hussein. 2018. Detection of Palm Tree Pests Using Thermal Imaging: A Review In: Hassanein, A.E., editor, Machine Learning Paradigms: Theory and Application. Springer, Cham. p. 253-270. doi:10.1007/978-3-030-02357-7_12

Akbari, M.H. 1996. Energy-based indicators of ecosystem health. Master thesis, University of Guelph.

Apostol, S., A.A. Viau, and N. Tremblay. 2007. A comparison of multiwavelength laser-induced fluorescence parameters for the remote sensing of nitrogen stress in field-cultivated corn. Can. J. Rem. Sens. 33:150-161. doi:10.5589/m07-022

Bai, H., and L.C. Purcell. 2018. Aerial canopy temperature differences between fast-and slow-wilting soya bean genotypes. J. Agron. Crop Sci. 204:243-251. doi:10.1111/jac.12259

Blad, B.L., A. Bauer, J.L. Hatfield, E.T. Kanemasu, D.J. Major, R.J. Reginato, and K.G. Hubbard. 1988. Influence of water and nitrogen levels on canopy temperatures of winter wheat grown in the North American Great Plains. Agric. For. Meteorol. 44:159-173. doi:10.1016/0168-1923(88)90015-9

Bonati, A., G. De Luca, S. Fabozzi, N. Massarotti, and L. Vanoli. 2019. The integration of exergy criterion in energy planning analysis for $100 \%$ renewable system. Energy 174:749-767. doi:10.1016/j. energy.2019.02.089 
Carroll, D.A. 2015. Drought and nitrogen effects on maize canopy temperature and stress indices. Master thesis, University of Brigham Young.

Cengel, Y.A., and M.A. Boles. 2002. Thermodynamics: An engineering approach.

Chauhan, B.S., and J.L. Opeña. 2013. Effect of plant geometry on growth and yield of corn in the rice-corn cropping system. Am. J. Plant Sci. 4:1928-1931. doi:10.4236/ajps.2013.410237

Chlingaryan, A., S. Sukkarieh, and B. Whelan. 2018. Machine learning approaches for crop yield prediction and nitrogen status estimation in precision agriculture: A review. Comput. Electron. Agric. 151:6169. doi:10.1016/j.compag.2018.05.012

Cools, T., and L. De Veylder. 2009. DNA stress checkpoint control and plant development. Curr. Opin. Plant Biol. 12:23-28. doi:10.1016/j. pbi.2008.09.012

Corti, M., D. Cavalli, G. Cabassi, P.M. Gallina, and L. Bechini. 2018. Does remote and proximal optical sensing successfully estimate maize variables? A review. Eur. J. Agron. 99:37-50. doi:10.1016/j. eja.2018.06.008

Das, B., G.R. Mahajan, and R. Singh. 2018. Hyperspectral Remote Sensing: Use in Detecting Abiotic Stresses in Agriculture In: Bal, S.K., J. Mukherjee, B.U. Choudhury, A.K. Dhawan, editors, Advances in Crop Environment Interaction. Springer, Singapore. p. 317-335. doi:10.1007/978-981-13-1861-0_12

Di Felice, F., A. Mazzini, G. Di Stefano, and G. Romeo. 2018. Drone high resolution infrared imaging of the Lusi mud eruption. Mar. Pet. Geol. 90:38-51. doi:10.1016/j.marpetgeo.2017.10.025

Dovrat, G., T. Masci, H. Bakhshian, E. Mayzlish Gati, S. Golan, and E. Sheffer. 2018. Drought-adapted plants dramatically downregulate dinitrogen fixation: Evidences from Mediterranean legume shrubs. J. Ecol. 106:1534-1544. doi:10.1111/1365-2745.12940

Duncan, W.G., A.L. Hatfield, and J.L. Ragland. 1965. The Growth and Yield of Corn. II. Daily Growth of Corn Kernels 1. Agron. J. 57:221-223. doi:10.2134/agronj1965.00021962005700020026x

Finn, J.T. 1988. RE Ulanowicz: Growth and development: Ecosystems phenomenology. New York, Springer-Verlag. Syst. Res. Behav. Sci. 33:158-159. doi:10.1002/bs.3830330206

Fraser, R., and J.J. Kay. 2004. Exergy analysis of ecosystems: Establishing a role for thermal remote sensing. Thermal Remote Sensing in Land Surface Processing. Taylor and Francis, London. P 283-360. doi:10.1201/9780415302241

Fuchs, M. 1990. Infrared measurement of canopy temperature and detection of plant water stress. Theor. Appl. Climatol. 42:253-261. doi:10.1007/BF00865986

Gaudreau, K. 2009. Exergy analysis and resource accounting. Master thesis, University of Waterloo.

Glansdorff, P., and I. Prigogine. 1971. Thermodynamic theory of structure, stability and fluctuations. New York: Wiley-Interscience.

Goffart, J.P., M. Olivier, and M. Frankinet. 2008. Potato crop nitrogen status assessment to improve $\mathrm{N}$ fertilization management and efficiency: Past present future. Potato Res. 51:355-383. doi:10.1007/ s11540-008-9118-x

Gong, S., and D.M. Wasserman. 2019. U.S. Patent Application No. $15 / 462,238$.

Harvey, P. 2016. Exiftool (version 10.26). http://www.sno.phy.queensu. $\mathrm{ca} / \sim$ phil/exiftool/.

Heege, H.J., S. Reusch, and E. Thiessen. 2008. Prospects and results for optical systems for site-specific on-the-go control of nitrogentop-dressing in Germany. Precis. Agric. 9:115-131. doi:10.1007/ s11119-008-9055-3

Idso, S.B., R.D. Jackson, P.J. Jr. Pinter, R.J. Reginato, and J.L. Hatfield. 1981. Normalizing the stress degree-day parameter for environmental variability. Agric. Meteorol. 24:45-55. doi:10.1016/0002-1571(81)90032-7
Israel, M. 2016. Entwicklung eines UAV-basierten Systems zur Rehkitzsuche und Methoden zur Detektion und Georeferenzierung von Rehkitzen in Thermalbildern: Der Fliegende Wildretter. Ph.D. diss., Universität Osnabrück.

Jackson, R.D. 1982. Canopy temperature and crop water stress. In: D. Hillel, editor, Advances in irrigation. Elsevier. 1:43-85. doi:10.1016/ B978-0-12-024301-3.50009-5

Jackson, R.D., S.B. Idso, R.J. Reginato, and P.J. Pinter. 1981. Canopy temperature as a crop water stress indicator. Water Resour. Res. 17:11331138. doi:10.1029/WR017i004p01133

Jones, H.G., M. Stoll, T. Santos, C.D. Sousa, M.M. Chaves, and O.M. Grant. 2002. Use of infrared thermography for monitoring stomatal closure in the field: Application to grapevine. J. Exp. Bot. 53:22492260. doi:10.1093/jxb/erf083

Jørgensen, S.E. 2000. Application of exergy and specific exergy as ecological indicators of coastal areas. Aquat. Ecosyst. Health Manage. 3:419-430. doi:10.1016/S1463-4988(00)00034-8

Kay, J.J. 2000. Ecosystems as Self-organising Holarchic Open Systems: Narratives and the Second Law of Thermodynamics. In: Jørgensen, S.E., F. Müller, editors, Handbook of Ecosystem Theories and Management. CRC Press, Boca Raton, FL. p.135-160.

Khanal, S., J. Fulton, and S. Shearer. 2017. An overview of current and potential applications of thermal remote sensing in precision agriculture. Comput. Electron. Agric. 139:22-32. doi:10.1016/j. compag.2017.05.001

Kimes, D.S., S. B. Idso, P.J. Pinter, R.J. Reginato, and R.D. Jackson. 1980. View angle effects in the radiometric measurement of plant canopy temperatures. Remote Sens. Environ. 10:273-284. doi:10.1016/0034-4257(80)90087-5

Kirkham, M.B. 2005. Principles of soil and plant water relations. Elsevier Academic Press, Amsterdam.

Knížková, I., P. Kunc, M. Koubková, J. Flusser, and O. Dolezal. 2002. Evaluation of naturally ventilated dairy barn management by a thermographic method. Livest. Prod. Sci. 77:349-353. doi:10.1016/ S0301-6226(02)00062-3

Knudsen, P.N. 2016. Testing and analysis of an exergetically efficient 4 $\mathrm{K}$ to $2 \mathrm{~K}$ helium heat exchanger. Ph.D. diss., Old Dominion Univ., Norfolk, VA.

Krayenhoff, E., and J. Voogt. 2016. Daytime thermal anisotropy of urban neighbourhoods: Morphological causation. Remote Sens. 8(2):108 doi:10.3390/rs8020108

Lambers, H., F.S. Chapin, and T.L. Pons. 2008. Photosynthesis In: Plant physiological ecology. Springer, New York. doi:10.1007/978-0-387-78341-3_2

Lawrence, R. 2016. Thermal Remote Sensing and the Exergy Destruction Principle Applied to Precision Agriculture. Master thesis, University of Waterloo.

Lee, U., C. Wie, B.O. Fernandez, M. Feelisch, and E. Vierling. 2008. Modulation of nitrosative stress by $S$-nitrosoglutathione reductase is critical for thermotolerance and plant growth in Arabidopsis. Plant Cell 20:786-802. doi:10.1105/tpc.107.052647

Lin, H., H. Zhang, and Q. Song. 2018. Transition from abstract thermodynamic concepts to perceivable ecological indicators. Ecol. Indic. 88:37-42. doi:10.1016/j.ecolind.2018.01.001

Lu, C.M., and J.H. Zhang. 2000. Photosystem II photochemistry and its sensitivity to heat stress in maize plants as affected by nitrogen deficiency. J. Plant Physiol. 157:124-130. doi:10.1016/ S0176-1617(00)80145-5

Luvall, J.C., and H.R. Holbo. 1989. Measurements of short-term thermal responses of coniferous forest canopies using thermal scanner data. RemoteSens.Environ.27:1-10.doi:10.1016/0034-4257(89)90032-1

Maes, W.H., and K. Steppe. 2012. Estimating evapotranspiration and drought stress with ground-based thermal remote sensing in agriculture: A review. J. Exp. Bot. 63:4671-4712. doi:10.1093/jxb/ers165 
Maes, W.H., A.R. Huete, and K. Steppe. 2017. Optimizing the processing of UAV-based thermal imagery. Remote Sens. 9(5):476 doi:10.3390/ rs 9050476

Martínez, D., and J. Guiamet. 2004. Distortion of the SPAD 502 chlorophyll meter readings by changes in irradiance and leaf water status. Agronomie 24:41-46. doi:10.1051/agro:2003060

Minkina, W., and S. Dudzik. 2009. Infrared thermography: Errors and uncertainties. John Wiley \& Sons, West Sussex, UK. doi:10.1002/9780470682234

Muñoz-Huerta, R., R. Guevara-Gonzalez, L. Contreras-Medina, I. Torres-Pacheco, J. Prado-Olivarez, and R. Ocampo-Velazquez. 2013. A review of methods for sensing the nitrogen status in plants: Advantages, disadvantages and recent advances. Sensors (Basel) 13:1082310843. doi:10.3390/s130810823

Nanda, M.K., U. Giri, and N. Bera. 2018. Canopy Temperature-Based Water Stress Indices: Potential and Limitations In: Bal, S., J. Mukherjee, B. Choudhury, A. Dhawan, editors, Advances in Crop Environment Interaction. Springer, Singapore. p. 365-385. doi:10.1007/978-981-13-1861-0_14

Neild, R.E., and J.E. Newman. 1990. Growing season characteristics and requirements in the Corn Belt. In: Dale, R.F., D.G. Hanway, R.E. Carlson, G.O. Benson, R.E. Felch, C.M. Sakamoto, et al., editors, National Corn Handbook. Purdue University, West Lafayette, IN.

Niklaus, F., C. Vieider, and H. Jakobsen. 2008. MEMS-based uncooled infrared bolometer arrays: A review In: Chiao, J.C., X. Chen, Z. Zhou, X. Li, editors, MEMS/MOEMS technologies and applications III. International Society for Optics and Photonics. Bellingham, WA. doi:10.1117/12.755128

Otsu, N. 1979. A threshold selection method from gray-level histograms. IEEE Trans. Syst. Man Cybern. 9:62-66. doi:10.1109/ TSMC.1979.4310076

Padilla, F., M. Gallardo, M. Peña-Fleitas, R. de Souza, and R. Thompson. 2018. Proximal optical sensors for nitrogen management of vegetable crops: A review. Sensors (Basel). 8(7):2083. doi:10.3390/s18072083

Padilla, F.M., R. de Souza, M.T. Peña-Fleitas, R. Grasso, M. Gallardo, and R.B. Thompson. 2019. Influence of time of day on measurement with chlorophyll meters and canopy reflectance sensors of different crop N status. Precis. Agric. 20:1-20.

Prigogine, I. 1991. Schrödinger and the riddle of life. Molecular theories of cell life and death. P 239-242.

Quattrochi, D.A., and J.C. Luvall, editors. 2004. Thermal remote sensing in land surface processing. CRC Press, Boca Raton, FL. doi:10.1201/9780203502174

Ratliff, L.F., J.T. Ritchie, and D.K. Cassel. 1983. Field-measured limits of soil water availability as related to laboratory-measured properties. Soil Sci. Soc. Am. J. 47:770-775. doi:10.2136/ sssaj1983.03615995004700040032x

Schneider, E.D., and J.J. Kay. 1994a. Complexity and thermodynamics: Towards a new ecology. Futures 26:626-647. doi:10.1016/0016-3287(94)90034-5
Schneider, E.D., and J.J. Kay. 1994b. Life as a manifestation of the second law of thermodynamics. Math. Comput. Model. 19:25-48. doi:10.1016/0895-7177(94)90188-0

Schrödinger, E. 1944. What is life? The physical aspect of the living cell and mind. Cambridge: Cambridge Univ. Press.

Shrestha, D.S., B.L. Steward, and S.J. Birrell. 2004. Video processing for early stage maize plant detection. Biosyst. Eng. 89:119-129. doi:10.1016/j.biosystemseng.2004.06.007

Subedi, K.D., and B.L. Ma. 2009. Assessment of some major yield-limiting factors on maize production in a humid temperate environment. Field Crops Res. 110:21-26. doi:10.1016/j.fcr.2008.06.013

Sui, R., R.K. Byler, and C.D. Delhom. 2017. Effect of nitrogen application rates on yield and quality in irrigated and rainfed cotton. J. Cotton Sci. 21:113-121.

Sui, X., Q. Chen, and G. Gu. 2013. Nonuniformity correction of infrared images based on infrared radiation and working time of thermal imager. Optik. 124:352-356. doi:10.1016/j.ijleo.2011.12.055

Tremblay, N., Z. Wang, and Z.G. Cerovic. 2012. Sensing crop nitrogen status with fluorescence indicators. A review. Agron. Sustain. Dev. 32:451-464. doi:10.1007/s13593-011-0041-1

Valero, A. 2008. Exergy Evolution of the Mineral Capital on Earth. Ph.D. diss., Univ. of Zaragoza. Zaragoza, Spain. p. 1-481.

Vigneau, N., M. Ecarnot, G. Rabatel, and P. Roumet. 2011. Potential of field hyperspectral imaging as a nondestructive method to assess leaf nitrogen content in Wheat. Field Crops Res. 122:25-31. doi:10.1016/j.fcr.2011.02.003

Wall, G. 1977. Exergy-a useful concept within resource accounting. Chalmers tekniska högskola, Göteborgs universitet.

Ward, N.C. 2015. Nitrogen and water effects on canopy sensor measurements for site-specific management of crops.

Xie, C., C. Yang, Jr., A. Hummel, G.A. Johnson, and F.T. Izuno. 2018. Spectral reflectance response to nitrogen fertilization in field grown corn. Int. J. Agric. Biol. Eng. 11:118-126.

Xiong, D., J. Chen, T. Yu, W. Gao, X. Ling, Y. Li, and J. Huang. 2015. SPAD-based leaf nitrogen estimation is impacted by environmental factors and crop leaf characteristics. Sci. Rep. 5:13389 doi:10.1038/ srep13389

Yao, H., Y. Huang, Z. Hruska, S.J. Thomson, and K.N. Reddy. 2012. Using vegetation index and modified derivative for early detection of soybean plant injury from glyphosate. Comput. Electron. Agric. 89:145-157. doi:10.1016/j.compag.2012.09.001

Yazici, K., and L. Kaynak. 2006. Effects of air temperature, relative humidity and solar radiation on fruit surface temperatures and sunburn damage in pomegranate (Punica granatum L. cv. Hicaznar). International Symposium on Pomegranate and Minor Mediterranean Fruits. 818: 181-186.

Zhang, J., A.M. Blackmer, and T.M. Blackmer. 2009. Reliability of chlorophyll meter measurements prior to corn silking as affected by the leaf change problem. Commun. Soil Sci. Plant Anal. 40:2087-2093. doi:10.1080/00103620902960609 